RASĀYAN J. Chem.

Vol. 13 | No. 2 |1193-1198| April - June | 2020 ISSN: 0974-1496 | e-ISSN: 0976-0083 | CODEN: RJCABP http://www.rasayanjournal.com http://www.rasayanjournal.co.in

\title{
SYNTHESIS OF NEW FUSED RING SULTONE FROM EUGENOL AND ITS DERIVATIVES
}

\author{
I. M. Sudarma*, R. Hidayati and M.G. Darmayanti \\ Department of Chemistry, University of Mataram, Mataram-83125, Indonesia \\ *E-mail: sud_arma@yahoo.co.id
}

\begin{abstract}
The main goal of this study is to compare reactivity and stability of eugenol (1), methyl eugenol (2), and eugenyl acetate (3) in sulfonation reaction to produce new fused ring sultone derivatives. Isolated eugenol can be easily derivatised to methyl eugenol (2) and eugenil acetate (3) using dimethyl sulfate and acetate anhydride respectively. Eugenol (1), methyl eugenol (2), and eugenil acetate (3) separately react with chlorosulfuric acid to produce new fused ring sultone derivatives in different yields. Methyl eugenol (2) gave a more stable product compare to eugenol (1) and eugenyl acetate (3).
\end{abstract}

Keywords: Reactivity, Stability, Eugenol, Methyl Eugenol, Eugenyl Acetate, Fused Ring Sultone

(C) RASĀYAN. All rights reserved

\section{INTRODUCTION}

A functional group or substituent is a specific moiety that is responsible for the biological, physical, chemical properties of the compound. The character and identity of the compound depend on the functional groups, structurally eugenol, methyl eugenol, and eugenyl acetate are only different in their functional group attached at 1 position. The compounds have $-\mathrm{OH}$, -OMe, and -OCOMe functional groups respectively (Fig.-1).<smiles>C=CCc1ccc(O)c(OC)c1</smiles>

(1)<smiles>C=CCc1ccc(OC)c(OC)c1</smiles>

(2)<smiles>C=CCc1ccc(OC(C)=O)c(OC)c1</smiles>

(3)

Fig.-1. Chemical Structures of Eugenol (1), Methyl Eugenol (2) and Eugenyl Acetate (3)

Cloves (Syzygium aromaticum) are a well known plant source of eugenol and contained about $70-96 \%$ of eugenol. ${ }^{1,2}$ Eugenol shows widely biological activities such as anticancer ${ }^{3}$, antimicrobial ${ }^{4-6}$, antioxidant ${ }^{7,8}$, anti-imflammatory $^{9}$, antibacterial ${ }^{10}$, acaricidal ${ }^{11,12}$, dental caries $^{13}$, and antitumor ${ }^{14}$. Eugenol (1) has been used as a starting material for organic synthesis ${ }^{15-18}$. Eugenol can be easily transformed into methyl eugeno $^{19}$ and eugenil acetate ${ }^{20}$. Methyl eugenol also exhibits antifungal ${ }^{21}$, antibacterial ${ }^{22}$, nematicidal ${ }^{23}$, antiimflamation ${ }^{24}$, anticancer ${ }^{25}$, and food flavouring ${ }^{26}$ while eugenyl acetate demonstrates antimicrobial ${ }^{27}$, 28 and toxic against Artemia salina. ${ }^{29}$

Eugenol and its methyl, acetyl derivatives undergo substitution reaction due to the presence of benzene ring and also undertake addition reaction due to occupancy of alkene moiety. Eugenol (1) and its methyl, acetyl derivatives are compound alike to benzene with hydroxyl, methoxyl, acetyl, and alkene substituents and the substituents lead the regioselectivity for further reaction. ${ }^{30}$ The presence of alkene substituent at the terminal of allyl moiety will undergo Markovnikov addition reaction by strong acids such as 
RASĀYAN J. Chem.

Vol. 13 | No. 2 |1193-1198| April - June | 2020

chlorosulfonic acid and produce sultone derivatives. ${ }^{31-33}$ Sultones are widely used in industry and having commercial application in detergents, polymers, antistatics. ${ }^{34}$ Synthesis of sultone is not remarkable progress and only few are reported. ${ }^{35,36}$

\section{EXPERIMENTAL}

\section{Materials}

The cloves were bought from Gangga, West Lombok of Indonesia. The reagent and chemicals were gained from Merck and Sigma included: 3 solvents (hexane, dichloromethane, and methanol), eugenol standard, sodium carbonate anhydrous, sodium hydroxide pellet, chlorosulfonic acid, dimethyl sulfate, acetate anhydride, silica gel 40-60 mesh for chromatography, and aluminium sheet thin layer chromatography (TLC).

\section{Instruments}

The chromatograms of GC-MS were obtained on Shimadzu QP-2010 Ultra. The spectra of ${ }^{1} \mathrm{H}$ NMR were obtained in $\mathrm{CDCl}_{3}$ on a Bruker spectrometer (400 MHz).

\section{Extraction and Isolation of Eugenol (1)}

Powder of clove $(50 \mathrm{~g})$ was extracted with dichloromethane for 48 hours to provide oil $(19.5 \mathrm{~g}, 39 \%)$. Chromatography was used to purify eugenol (1) $(7.80 \mathrm{~g})(78 \%)$ and identified by GC-MS analyses, $\mathrm{M}^{+}$. 164, calculated for $\mathrm{C}_{10} \mathrm{H}_{12} \mathrm{O}_{2}$. Fragments: $149\left(\mathrm{M}^{+} \cdot-\mathrm{CH}_{3}\right), 131,121,103,91,77\left(\mathrm{C}_{6} \mathrm{H}_{6}\right.$, base peak $) ;{ }^{1} \mathrm{H}$ NMR: $\delta 3.81\left(3 \mathrm{H}, \mathrm{s}\right.$, Aromatic $\left.-\mathrm{OCH}_{3}\right), 5.05\left(2 \mathrm{H}, \mathrm{m},=\mathrm{CH}_{2}\right), 5.53(2 \mathrm{H}, \mathrm{m}$, Aromatic $-\mathrm{OH}$ and $-\mathrm{HC}=)$, 5.91 $\left(2 \mathrm{H}, \mathrm{m},-\mathrm{CH}_{2}-\right), 6.66(1 \mathrm{H}, \mathrm{s}$, Aromatic $\mathrm{H}), 6.67(1 \mathrm{H}, \mathrm{d}$, Aromatic $\mathrm{H}), 6.82(1 \mathrm{H}, \mathrm{d}$, Aromatic $\mathrm{H})$, and also confirmed by TLC of eugenol standard.

\section{Preparation of Methyl Eugenol (2)}

Three necks round-bottomed flask $(100 \mathrm{~mL})$ and fit-out with a condenser was filled with eugenol $(5 \mathrm{~g})$ and sodium hydroxide ( $2 \mathrm{~g}$ in $20 \mathrm{~mL}$ of distilled water) and further stirred $(15 \mathrm{~min}$.). Dimethyl sulfate (4.0 $\mathrm{mL}$ ) was added drops by drop and stirring $\left(30 \mathrm{~min}\right.$.) and refluxed at $103^{\circ} \mathrm{C}(1 \mathrm{~h}$.), and after worked up to give an oil (86.58\%). GC-MS gave molecular ion $\left(\mathrm{M}^{+} \cdot 178\right.$, calculated for $\left.\mathrm{C}_{11} \mathrm{H}_{14} \mathrm{O}_{2}\right)$. Fragmentations: 163 $\left(\mathrm{M}^{+}-\mathrm{CH}_{3}\right), 147\left(\mathrm{M}^{+}-\mathrm{OCH}_{3}\right), 135,115,107,91,77\left(\mathrm{C}_{6} \mathrm{H}_{6}\right) .{ }^{1} \mathrm{HNMR}: \delta 3.77\left(3 \mathrm{H}, \mathrm{s}\right.$, Aromatic $\left.-\mathrm{OCH}_{3}\right)$, $3.83\left(3 \mathrm{H}, \mathrm{s}\right.$, Aromatic $\left.-\mathrm{OCH}_{3}\right), 5.05\left(2 \mathrm{H}, \mathrm{m},=\mathrm{CH}_{2}\right), 5.50(1 \mathrm{H}, \mathrm{m},-\mathrm{HC}=), 5.91\left(2 \mathrm{H}, \mathrm{m},-\mathrm{CH}_{2}-\right), 6.66(1 \mathrm{H}, \mathrm{s}$, Aromatic $\mathrm{H}), 6.67(1 \mathrm{H}, \mathrm{d}$, Aromatic $\mathrm{H}), 6.82(1 \mathrm{H}, \mathrm{d}$, Aromatic $\mathrm{H})$.

\section{Preparation of Eugenol Acetate (3)}

This method was adopted from Sudarma et al. ${ }^{33}$ Eugenol $(2 \mathrm{~g})$, acetate anhydride (6 g), sodium carbonate $(2 \mathrm{~g})$, and ethyl acetate $(100 \mathrm{~mL})$ were mixed and stirred $(24 \mathrm{~h}$.). The mixture was filtered and evaporated to afford a residue. Water $(10 \mathrm{ml})$ was added and extracted with dichloromethane $(25 \mathrm{~mL})$. The dichloromethane layer was dried by sodium carbonate anhydrous and evaporated to afford eugenil acetate (3) $\left(1.1 \mathrm{~g}, 87.5 \%\right.$ ). This compound was analyzed by TLC, $\mathrm{R}_{\mathrm{f}} 0.78$ (eluent: $\mathrm{CH}_{2} \mathrm{Cl}_{2}$ ) and GC-MS: $\mathrm{M}^{+} \cdot 206$, calculated for $\mathrm{C}_{12} \mathrm{H}_{14} \mathrm{O}_{3}$, fragmentations: 77, 91, 103, 121, 131, 149, 164 (base peak). ${ }^{1} \mathrm{HNMR}$ : 2.31 (3H, $\left.\mathrm{s}, \mathrm{CH}_{3} \mathrm{CO}_{2}\right) ; 3.37(2 \mathrm{H}, \mathrm{d}) ; 3.81\left(3 \mathrm{H}, \mathrm{s}, \mathrm{OCH}_{3}\right) ; 5.10(2 \mathrm{H}, \mathrm{m}) ; 5.97(1 \mathrm{H}, \mathrm{m}) ; 6.77(2 \mathrm{H}, \mathrm{m}) ; 6.94(1 \mathrm{H}, \mathrm{d})$.

\section{Synthesis of Sultone (4) from Methyl Eugenol (2)}

This method was adopted from Sudarma et al. ${ }^{32}$ Methyl eugenol (2) $(100 \mathrm{mg})$ was dissolved in dichloromethane $(20 \mathrm{~mL})$ and added drops by drop chlorosulfonic acid $(2 \mathrm{~mL})$ with stirring for $(30 \mathrm{~min}$.) then refluxed for $(15 \mathrm{~min}$.). The dichloromethane was evaporated and added distilled water $(10 \mathrm{~mL})$, and adjusted to $\mathrm{pH} 8$ using $1 \mathrm{M} \mathrm{NaOH}$, then extracted with dichloromethane $(2 \times 50 \mathrm{~mL})$. The dichloromethane extract was dried with sodium carbonate anhydrous and evaporated to leave a gum, and recrystallized from methanol to sultone (4) $(84 \%)$. GC-MS: $\mathrm{M}^{+} \cdot 258$, cal for $\mathrm{C}_{11} \mathrm{H}_{14} \mathrm{SO}_{5}$, major fragments: 77, 107, 135, 150 (base peak), 179, 243. ${ }^{1} \mathrm{H}$ NMR: $\delta 1.62\left(3 \mathrm{H}, \mathrm{d}, \mathrm{J} 6.6 \mathrm{~Hz},-\mathrm{CH}_{3}\right) ; 2.85-2.31(2 \mathrm{H}, \mathrm{m},-$ $\left.\mathrm{CH}_{2}-\right) ; 3.83\left(3 \mathrm{H}, \mathrm{s},-\mathrm{OCH}_{3}\right) ; 3.93\left(3 \mathrm{H}, \mathrm{s},-\mathrm{OCH}_{3}\right) ; 5.20(1 \mathrm{H}, \mathrm{m},-\mathrm{CH}-) ; 6.60(1 \mathrm{H}, \mathrm{s}$, Aromatic $\mathrm{H}) ; 7.33(1 \mathrm{H}$, s, Aromatic H). 
RASĀYAN J. Chem.

Vol. 13 | No. 2 |1193-1198| April - June | 2020

\section{Synthesis of Sultone (5) from Eugenol (1)}

Round bottomed flask $(100 \mathrm{~mL})$ and fit-out with a condenser were charged with stirring dichloromethane $(50 \mathrm{~mL})$ and eugenol $(1 \mathrm{~g})$. This solution was added chlorosulfonic acid $(10 \mathrm{~mL})$ drops by drop and further stirred at ambient temperature for $(30 \mathrm{~min}$.) and refluxed for $(15 \mathrm{~min}$.). Work up as synthesis of sultone (4) to give an amorphous grey solid, and recrystallized from methanol to afford sultone (5) (73\%). GCMS gave molecular ion $\left(\mathrm{M}^{+} \cdot 244\right)$, calculated for $\mathrm{C}_{10} \mathrm{H}_{12} \mathrm{SO}_{5}$, major fragments: 136 (base peak), 151, 165, 183, 200. ${ }^{1} \mathrm{H}$ NMR $\left(400.1 \mathrm{MHz}, \mathrm{CDCl}_{3}\right): \delta 1.62\left(3 \mathrm{H}, \mathrm{d}, \mathrm{J} 6.6 \mathrm{~Hz},-\mathrm{CH}_{3}\right) ; 2.16(1 \mathrm{H}, \mathrm{s}, \mathrm{OH}) ; 2.85-2.31($ $\left.2 \mathrm{H}, \mathrm{m}, \mathrm{CH}_{2}\right) ; 3.93\left(3 \mathrm{H}, \mathrm{s},-\mathrm{OCH}_{3}\right) ; 5.20(1 \mathrm{H}, \mathrm{m},-\mathrm{CH}) ; 6.60(1 \mathrm{H}, \mathrm{s}$, Aromatic $\mathrm{H}) ; 7.33(1 \mathrm{H}, \mathrm{s}$, Aromatic $\mathrm{H})$.

\section{Synthesis of Sultone (5) from Eugenyl Acetate (3)}

The solution of eugenyl acetate (3) $(100 \mathrm{mg})$ in dichloromethane $(20 \mathrm{~mL})$ was filled chlorosulfonic acid $(2 \mathrm{~mL})$ drops by drop. The solution was stirred at ambient temperature for $(30 \mathrm{~min}$.) then refluxed for (15 min.). Work up as synthesis of sultone (4) to give an amorphous grey solid, and recrystallized from methanol to afford sultone (5) (96\%).

\section{RESULTS AND DISCUSSION}

Eugenol (1) is a naturally occurring compound that is easily isolated from clove oil and has been used for the synthesis of fused ring sultone derivatives via methyl eugenol (2) or eugenyl acetate (3) (Fig.-2).<smiles>C=CCc1ccc(OC)c(OC)c1</smiles>

(2)<smiles>C=CCc1cc(OC)c(O)c(OC)c1</smiles>

(1)

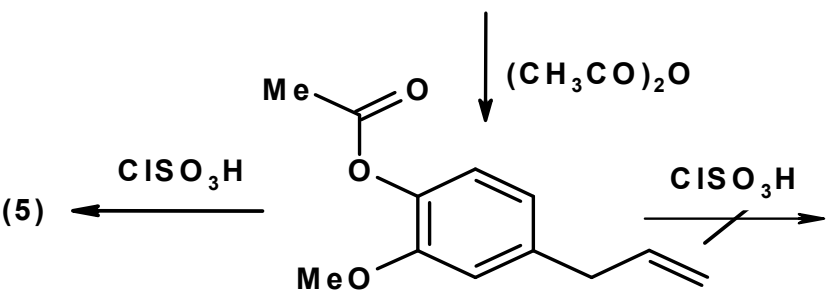

(3)<smiles>COc1cc2c(cc1OC)S(=O)(=O)OC(C)C2</smiles>

(4)<smiles>COc1cc2c(cc1O)S(=O)(=O)OC(C)C2</smiles>

(5)<smiles>[CH]C1Cc2cc(OC)c(OC(C)=O)cc2S(=O)(=O)O1</smiles>

(6)

Fig.-2: Synthesis of Sultone (4) and (5) from eugenol (1) and its Derivatives

Eugenol (1) is aromatic alcohol characterized by the presence of an -OH group and is possibly reduce the yield of sultone (5) $(73 \%)$ due to its reactivity against electrophilic aromatic substitution, oxidation, etc. The existing of hydroxyl group in eugenol (1) make it can form hydrogen bond and leads to increase boiling points. The presence of a strong base and also semi-polar solvents can deprotonate the hydroxyl group of eugenol (1) and make the difference in electronegativity between the carbon of aromatic ring and the oxygen atoms.

The yield of fused ring sultone derivatives could be increased, presumably by the protection of $-\mathrm{OH}$ group of eugenol (1), without protection the yield of sultone derivative (5) is $73 \%$ only ${ }^{32}$. Protection of - 
RASĀYAN J. Chem.

Vol. 13 | No. 2 |1193-1198| April - June | 2020

$\mathrm{OH}$ group is one common synthetic strategies, esterification and methylation are two ways to protect it. Eugenol (1) can be easily acylated by acetate anhydride with a catalyst to produce eugenyl acetate (3) in high yield ${ }^{17}$. Chemical transformation of eugenyl acetate (3) using chlorosulfonic acid expected to afford sultone (6), however, it produces sultone (5) in high yield (96 \%) (Fig.-3).

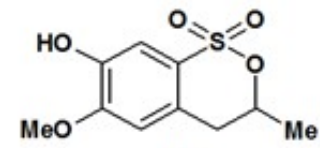

(5)

This product is similar to the chemical transformation of eugenol (1) with chlorosulfuric acid. The formation of sultone (5) is favor compare to sultone (6) due to its ester moiety can be cleavage with strong nucleophiles to produce alcohol or sultone derivative (5). Based on this reaction, ester protection is not appropriate to protect the $-\mathrm{OH}$ of eugenol (1) for further reaction and the more stable functional group is needed such as ether.

Eugenol (1) can be easily methylated with dimethyl sulfate to form ether functional group or methyl eugenol (2) in high yield (84\%). Sulfonation reaction of this compound with chlorosulfonic acid in the same manner of eugenol (1) and eugenyl acetate (3) leads to the formation of desire product, sultone derivative (4) (84.03\%). The chromatogram of GC-MS showed a peak of sultone (4) present at the retention time of 13.031 minutes (Fig.-4).<smiles>COc1cc2c(cc1OC)S(=O)(=O)OC(C)C2</smiles>

(4)

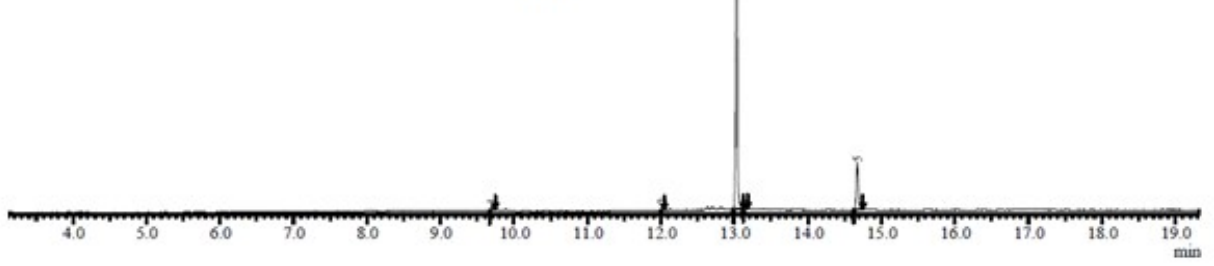

Fig.-4: Chromatogram of Sulfonation Reaction of Methyl Eugenol (2).

${ }^{1} \mathrm{H}$ nuclear magnetic resonance confirmed the difference between sultone derivative (4) and (5). Sultone derivative (4) gave two methoxyl groups at $\delta 3.83\left(3 \mathrm{H}, \mathrm{s},-\mathrm{OCH}_{3}\right)$ and $3.93\left(3 \mathrm{H}, \mathrm{s},-\mathrm{OCH}_{3}\right)$ while sultone derivative (5) gave one $-\mathrm{OH}$ at $\delta 2.16(1 \mathrm{H}, \mathrm{s}, \mathrm{OH})$ and one methoxyl at $\delta 3.93\left(3 \mathrm{H}, \mathrm{s},-\mathrm{OCH}_{3}\right)$.

The product of sulfonation reaction of eugenol (1), methyl eugenol (2), and eugenyl acetate (3) in the same condition was summarized in Table-1.

Table-1: Sulfonation of Eugenol (1), Methyl Eugenol (2), and Eugenol Acetate (3)

\begin{tabular}{l|l|l}
\hline \multicolumn{1}{c|}{ Starting Material } & \multicolumn{1}{|c|}{ Condition } & \multicolumn{1}{c}{ Product (\%) } \\
\hline Eugenol (1) & $\mathrm{ClSO}_{3} \mathrm{H} /$ Dichloromethane, rt. 0.5 h, reflux 15 min & Sultone (5) (73\%) \\
\hline Methyl eugenol (2) & $\mathrm{ClSO}_{3} \mathrm{H} /$ Dichloromethane, rt. 0.5 h, reflux 15 min & Sultone (4) $(84 \%)$ \\
\hline Eugenyl acetate (3) & $\mathrm{ClSO}_{3} \mathrm{H} /$ Dichloromethane, rt. 0.5 h, reflux 15 min & Sultone $(5)(96 \%)^{18}$ \\
\hline
\end{tabular}

Table-1 showed that sulfonation reaction of eugenol (1), methyl eugenol (2), and eugenyl acetate (3) separately gave significant differences in percent yield of sultone. Eugenol (1) gave in moderate yield 
RASĀYAN J. Chem.

Vol. 13 | No. 2 |1193-1198| April - June | 2020

(73\%) of sultone (5); methyl eugenol (2) produced in high yield (84\%) of sultone (4); eugenyl acetate (3) expected to produce sultone (6), however, its produced in high yield (96\%) of sultone (5). Acetyl group at sultone (6) was hydrolyzed to form sultone (5) due to the carbonyl of acetyl could be attacked by a strong nucleophile. Different reactivity and stability of eugenol (1), methyl eugenol (2), and eugenyl acetate (3) in sulfonation reaction would give a different yield of sultone derivatives. The $-\mathrm{OH}$ of eugenol presumably more reactive or less stable compare to methyl eugenol and eugenyl acetate.

\section{CONCLUSION}

Methyl eugenol (2) was more stable compare to eugenol (1) and eugenyl acetate (3) in sulfonation reaction to produce a new fused ring of sultone derivatives (4) and (5).

\section{ACKNOWLEDGMENT}

The University of Mataram and The Ministry of Culture and Education, the Republic of Indonesia highly appreciated Research Grant 2019/2020 to support the financing for this research works.

\section{REFERENCES}

1. J. Towaha, Perspektif Review Penelitian Tanaman Industri, 11(2), 78(2012)

2. F. R. Giuliani, ESSAI, 12, Article 19, (2014)

3. A. Carrasco, C. Espinoza, V. Cardile, C. Gallardo, W. Cardona, L. Lombardo, M. Catalán, F. Cuellar, A. Russo, Journal of Brazilian Chemical Society, 19(3), (2008), DOI:10.1590/S010350532008000300024

4. S. Ali, A. Khan, I. Ahmed, M. Musaddiq, K. Ahmed, H. Polasa, L. Rao, C. Habibullah, L. Sechi, N. Ahmed, Annal of Clinical Microbiology and Antimicrobial, 4, 20(2005), DOI:10.1186/1476-0711-420

5. A. Marchese, R. Barbieri, E. Coppo, I. Orhan, M. Daglia, S. Nabavi, M. Izadi, M. Abdollahi, S. Nabavi, M. Ajami, Critical Review in Microbiology, 43(6), 668(2017), DOI: 10.1080/1040841X.2017.1295225

6. S. Burt, R. Reinders, Letters in Applied Microbiology, 36(3), 162 (2003).

7. E. Nagababu, J. Rifkind, S. Boindala, L. Nakka, Methods in Molecular Biology, 610, 165 (2010),DOI:10.1007/978-1-60327-029-8_10

8. M.B. Hossain, N.P. Brunton, C. Barry-Ryan, A.B. Martin-Diana, and M. Wilkinson, Rasayan Journal of Chemistry, 1 (4), 751 (2008)

9. K. Thakur and K.S. Pitre, Rasayan Journal of Chemistry, 2 (2), 472 (2009),

10. I. M. Sudarma, M.G. Darmayanti, and Sarkono, Rasayan Journal of Chemistry, 12 (2), 761 (2019), DOI: $10.31788 /$ RJC.2019.1225115

11. C. Pasay, K. Mounsey, G. Stevenson, R. Davis, L. Arlian, M. Morgan, D. Vyszenski Moher, K. Andrews, J. McCarthy, Plos One, Tenth Anniversary, Published: August 11, (2010), DOI: 10.1371/journal.pone.0012079

12. S. Kim, J. Yi, J. Tak, Y. Ahn, Veterinary Parasitology, 120(4), 297 (2004), DOI: 10.1016/j.vetpar.2003.12.016

13. J. Xu, Y. Li, Y. Cui, Experimetal and Therapeutic Medicine, 5(6), 1667(2013)

14. D. Bezerra, G. Militão, M. Morais, D. Sousa, Nutrients, 9(12), 1367 (2017)

15. I M. Sudarma, A. Kusnandini, and M. G. Darmayanti, Journal of Natural Products, 8, 27 (2015)

16. I.M. Sudarma, A. Shahab, M. Azim, I.K. Putri, and M.G. Darmayanti, Asian Journal of Chemistry, 28(8), 1799 (2016), DOI:10.14233/ajchem.2016.19832

17. I.M. Sudarma, A.R. Satriani, and M.G. Darmayanti, Asian Journal of Chemistry, 29(4), 867 (2017), DOI:10.14233/ajchem.2017.20339

18. I.M. Sudarma, L. Supiani, A. Syafitri, W.K. Hidayati, H. Oltantia, and M.G. Darmayanti, Asian Journal of Chemistry, 30(11), 2411(2018), DOI:10.14233/ajchem.2018.21398

19. Riyanto, H. Sastrohamidjojo, E. Fariyatun, IOSR Journal of Applied Chemistry, 9(10), 105(2016), DOI: $10.9790 / 5736-091002105112$.

20. F. N. Lugemwa, KoonjShaikh and E. Hochstedt, Catalysts, 3, 954(2013) 
RASĀYAN J. Chem.

Vol. 13 | No. 2 |1193-1198| April - June | 2020

21. P. Sudhakar, P. Latha, Y. Sreenivasulu, B.V. Reddy, T. M. Hemalatha, M. Balakrishna, K.R. Reddy, Indian Journal of Experimental Biology, 47(1), 63 (2009)

22. P.G. Rossi, L. Bao, A. Luciani, J. Panighi, J.M. Desjobert, J. Costa, J. Casanova, J.M. Bolla, L. Berti, Journal Agriculture of Food Chemistry, 5, 7332 (2007)

23. I. K. Park, J. Kim, S. G. Lee, S. C. Shin, Journal of Nematology, 39(3), 275 (2007)

24. Y. K. Choi, G. S. Cho, S. Hwang, B.W. Kim, J. H. Lim, J. C. Lee, H. C. Kim, W. K. Kim, Y. S. Kim, Free Radical Research, 44(8), 925 (2010), DOI: 10.3109/10715762.2010.490837

25. L. Yin, Z. Sun, Q. Ren, X. Su, D. Zhang, Journal of B.U.ON: Official Journal of the Balkan Union of Oncology, 23(4), 1174 (2018)

26. R. L. Smith, T. B. Adams, J. Doull, V. J. Feron, J. I. Goodman, L. J. Marnett, P. S. Portoghese, W. J. Waddell, B. M. Wagner, A. E. Rogers, J. Caldwell, I. G. Sipes, Food Chemistry Toxicology, 40(7), $851(2002)$

27. A. B. Vanin, T. Orlando, S. P. Piazza, B. M. S. Puton, R. L. Cansian, D. Oliveira, N. Paroul, Applied Biochemistry and Biotechnology, 174(4), 1286 (2014)

28. K. S. Musthafa, S. P. Voravuthikunchai, Flavour and Fragrance Journal, 31(6), 448 (2016), DOI: $10.1002 / \mathrm{ffj} .3336$

29. R. L. Cansian, A. B. Vanin, T. Orlando, S. P. Piazza, B. M. S. Puton, R. I. Cardoso, I.L. Gonçalves, T. C. Honaiser, N. Paroul, D. Oliveira, Brazilian Journal of Biology, 77(1), (2016), DOI: 10.1590/15196984.12215

30. R.O.C. Norman and R. Taylor, Electrophilic Substitution in Benzenoid Compounds, Elsevier, Amsterdan, p. 301 (1965)

31. Alkene Reactivity, MSU https://www2.chemistry.msu.edu/faculty/reusch/virttxtjml/addene1.htm

32. 32. I M. Sudarma, E. Yuanita, I W. Suana, Indoneian Journal of Chemistry, 13(2), 181 (2013)

33. I.M. Sudarma, L. Supiani, A. Syafitri, W.K. Hidayati, H. Oltantia , and M.G. Darmayanti, Asian Journal of Chemistry, 30(11), 2411 (2018), DOI:10.14233/ajchem.2018.21398

34. O. O.B Soile, International Journal of Advancements in Research \& Technology, 3(10), (2014).

35. B. Li, W. Yan, C. Zhang, Y. Zhang, M. Liang, F. Chu,Y. Gong, B. Xu, P. Wang, and H. Lei, Molecules, 20, 4307 (2015), DOI:10.3390/molecules20034307

36. 36. H. Li, J. Zhou, X. Chen, Journal of Chemical Science and Technology, 2 (4), 209 (2013)

[RJC-5358/2019] 